Journal of Advanced College of Engineering and Management, Vol. 5, 2019

\title{
HEAT EXCHANGER FOR BIO-DIGESTER UNDER THERMOPHILC RANGE
}

\author{
Prajwal Sapkota ${ }^{1}$,Dr. Laxman Poudel ${ }^{2}$ \\ ${ }^{1}$ Department of Mechanical Engineering, Pulchowk Campus, T.U. \\ ${ }^{2}$ Associate Professor, Department of Mechanical Engineering,Pulchowk Campus, T.U.
}

\begin{abstract}
Bio-gas has been one of the sources of renewable energy and has been used from long time. It is produced by the anaerobic digestion or decomposition of organic compounds and has different process. The digestion process is carried out by bacteria present in the waste and it is highly dependent on the bacteria which work differently on different temperatures. The rate of anaerobic digestion is highest at thermophilic temperature $\left(55^{\circ} \mathrm{C}\right)$. Similarly, it is moderate at mesophilic temperature $\left(35^{\circ} \mathrm{C}\right)$ and is lowest at psychrophilic (below $20^{\circ} \mathrm{C}$ ). Thus, to attain the highest digestion rate a thermophilic heating system has been developed. The heating system uses five heat exchangers to heat the influent at digester which is of $35 \mathrm{~m}^{3}$ volume, to maintain temperature at $56^{\circ} \mathrm{C}$. The volume of bio-gas production from this system which uses cow dung as digesting material is about $28 \mathrm{~m}^{3}$ per day.
\end{abstract}

Keywords: Digester; Heating; Bio-gas; Heat Exchanger; Thermophilic; Design; Anaerobic digestion

\section{Background}

Different sources of energy are used in our daily life including both renewable and non-renewable sources. Biogas is one of the renewable sources of energy in which organic wastages are converted into gas using anaerobic digestion or fermentation or decomposition of organic wastages(Alternate Energy Promotion Center, 2017). Biogas is among one of the good techniques for the management of organic wastages and energy recovery (Alternate Energy Promotion Center, 2017).

Bio gas has different advantages. It can be used for cooking, lighting and heating purposes along with the utilization of waste cow dung. It has good environmental benefits as methane produced by waste cow has been regarded as the source of greenhouse gases. Thus, reduces greenhouse gas production. Similarly, Bio gas has been beneficial from the socio economic perspective. Bio gas reduces the fuel consumption and saves the overall cost of fuel creating a societal impact on uplifting the life standard of people and reducing the foreign fuel dependency.

Nepal has geographical variations. It consists of three different geographical regions that are mountains, hills and plain land(Basnet, 1989-92). The variation in the geography or altitude is the cause of temperature variations in these reasons. The plain reason is almost hotter than other regions(Basnet, 1989-92). Similarly, the hilly region has moderate temperatures and the mountains are the coldest due to high altitude (Basnet, 1989-92).

For the anaerobic digestion, temperature is one of the important parameter that needs to be considered. As of the biogas yield, three different temperatures ranges have been defined which are psychrophilic (below $\left.20^{\circ} \mathrm{C}\right)$, mesophilic $\left(20^{\circ} \mathrm{C}-45^{\circ} \mathrm{C}\right)$ and thermophilic $\left(45^{\circ} \mathrm{C}-60^{\circ} \mathrm{C}\right)(\mathrm{B}$., et al., 2014). Biogas production rate increases with the increase in temperature and hydraulic retention time decreases with the increase in temperature(B., et al., 2014). Bio-gas yield stops below $10^{\circ} \mathrm{C}$ and gas yield is maximum at $35^{\circ} \mathrm{C}$ on the mesophilic condition (B., et al., 2014). Similarly, gas yield will be maximum at $55^{\circ} \mathrm{C}$ on the thermophilic condition (B., et al., 2014). The major challenge for the gas yield is to maintain the constant temperature condition(B., et al., 2014). To obtain a maximum yield 
of bio gas at thermophilic temperature, heat exchanging systemhas to be designed to heat the manure $\&$ loss of heat from the wall of digester has to be prevented.

\section{Methodology}

Before starting the design of the bio gas digester heating system, a proper methodology has been developed. Different literatures have been studied throughout the research period for references of different equations, data and methods used. The literatures include bio gas digestion process, its calculations, heating methods, insulation design \& calculation, heat exchangers, heat transfer etc. The standard plant volume of bio gas plant of $35 \mathrm{~m}^{3}$ has been selected which uses cow dung as digesting material. The methodology for the computation of total production of bio gas from the bio gas plant has been developed using different references.

The thermophilic digestion is very sensitive to temperature. So, influent manure can't be directly mixed. Thus, preheating procedure using a shell and tube heat exchanger has been developed. Similarly, to prevent heat loss from the digester, an insulating system has been used. The heat conduction equation has been used to calculate heat loss. An insulating material of calculated thickness has been used to prevent heat loss in significant amount.

The important part of this research is to design the heating system to heat large mass of influent and work within small temperature difference i.e. $52^{\circ} \mathrm{C}-58^{\circ} \mathrm{C}$. Heating of influent in the inlet and digester, have been carried out using heat exchangers to heat the influent manure up to the operating temperature. The standard methodology for the design of shell and tube exchangers has been followed. The heat exchange has been carried out using the concurrent flow of heat transfer. The convective heat transfer coefficients of fluids have been calculated using convection heat transfer equation for different Reynolds number.

\section{Result\& Discussion}

The operating temperature for the digester is the thermophilic temperature $\left(55^{\circ} \mathrm{C}\right)$ and standard digester of plant volume $35 \mathrm{~m}^{3}$ has been selected. The results from the previous study demonstrate that, a stable digester operation at thermophilic conditions is well possible on the cattle manure, as manifested in a constant methane production (El-Mashad, 2005). Also, it has been said that, such a stable operation can be achieved after imposing short-term downward temperature changes to the system (El-Mashad, 2005)

\section{Bio-Gas Production}

The hydraulic retention time for the thermophilic digestion is about 15 days. For $35 \mathrm{~m}^{3}$ of digester, 700 $\mathrm{kg}$ of substrate and 855 liters of water is required daily to produce gas of 28 cubic meters per day. The result has been summarized below.

\begin{tabular}{|l|l|l|}
\hline S.N & Parameters & Value \\
\hline 1 & Substrate (Manure) Required & $700 \mathrm{~kg}$ \\
\hline 2 & Water Required & $855 \mathrm{liter}$ \\
\hline 3 & Gas Production & $28 \mathrm{~m}^{3} / \mathrm{day}$ \\
\hline 4 & Slurry Production & $1555 \mathrm{~kg} /$ day \\
\hline 5 & No of Cattles to produce waste & $47 \mathrm{big}$ cows \\
\hline
\end{tabular}




\section{Dimension of Bio-Gas Plant}

The Figure 1 shows the dimension of Bio Gas plant that has the digester diameter of 4450 millimeters. The total height of the digester is about 2840 millimeters. The height of digester excluding the height of dome is about 1500 millimeters. And the thickness of concrete is about $150 \mathrm{~mm}$.

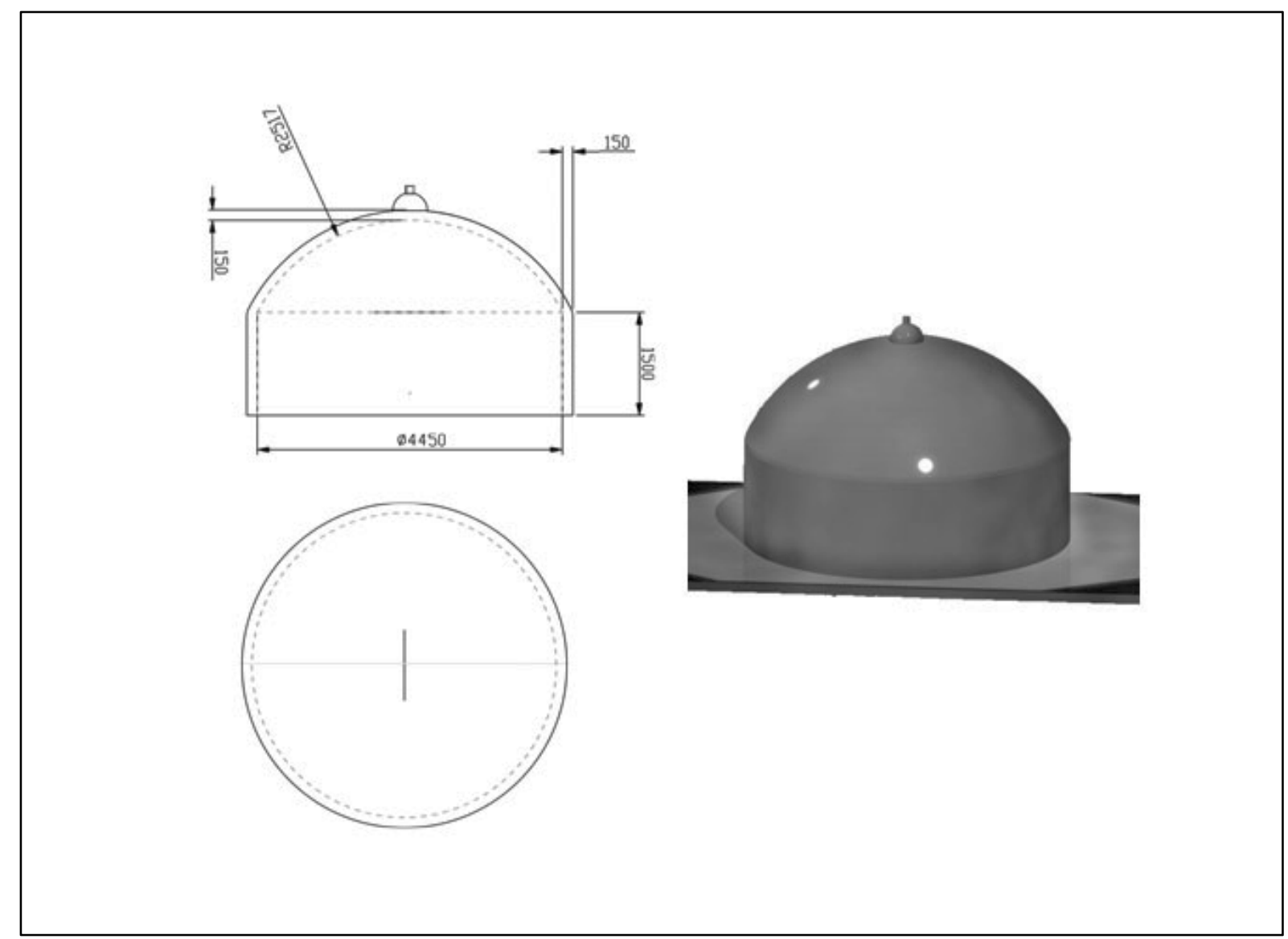

Figure 1: Dimension of Bio Gas Plant in mm.

\section{Daily Influent Heating}

The influent (manure) is mixed with the water before sending it to the digester. The water required to mix the different mass of substrate has been calculated. The method for mixing is according to targeting the total solid of waste to be $9 \%$. For e.g. $700 \mathrm{~kg}$ of manure require 855 liters of water to dilute and maintain its total solid to be $9 \%$.

The $F$ shows the linear relationship between substrate production and water requirement. Since there is no certainty on the production of substrate, the following graph can be helpful to calculate the water requirement for the different substrateproduction.

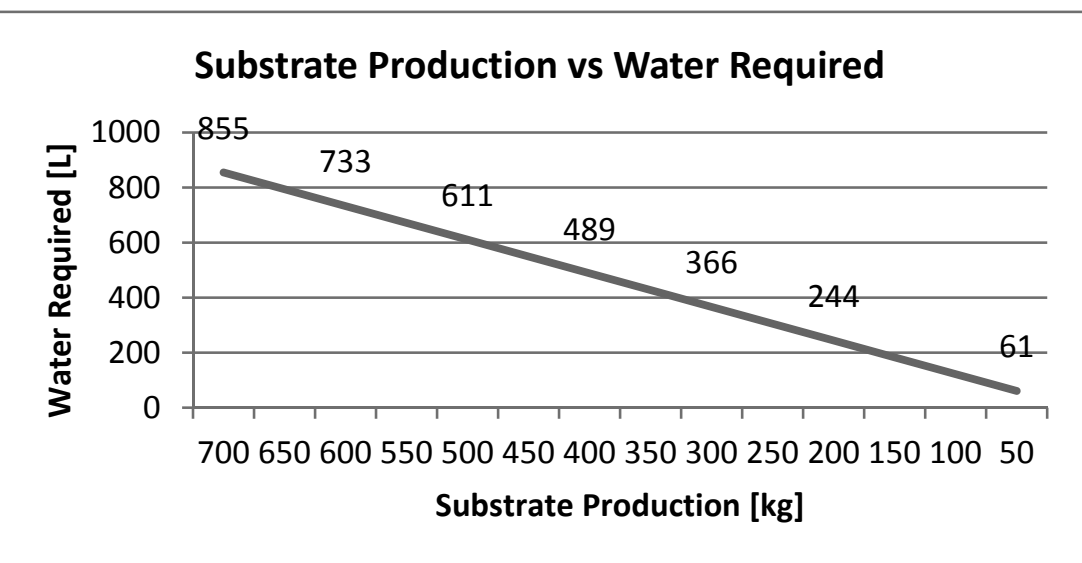

Figure 2: Graph for Calculating the Water Required for Varying Substrate 


\section{Heating Load Computation}

A heat exchanger is used for heating the cold water and influent mixture before that is sent to the digester. Before selecting heat exchanger heating loads needs to be calculated.

The above result is useful to know the heating requirements for different ambient

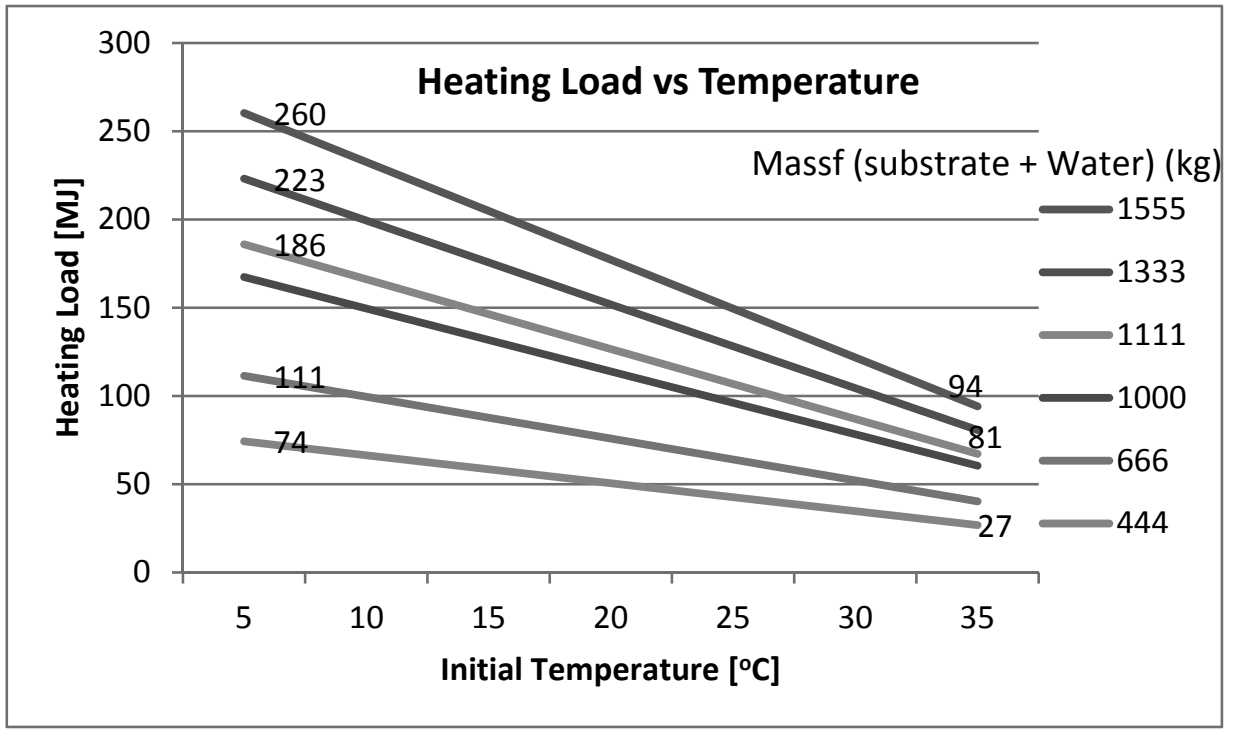

Figure 3: Heating Load on Varying Temperature with Different Mass temperatures. Design of heat exchangers is considered at extreme condition, so that heat exchanger can operate at the most extreme condition.

The graph shows that, the total heating load for the mass of influent of 1555 kilograms at initial temperature of 5 degree Celsius to final temperature of 52 degree is about 260 mega joules. Similarly, the heating load for the mass of 444 kilograms of influent at initial temperature of 35 degree Celsius to final temperature of 52 degree Celsius is about 27 mega joules.

\section{Heat Exchanger}

Before mixing the influent at the digester, a heat exchanger has been successfully designed that is capable to maintain the temperature of influent to 52 degree Celsius at the outlet which was initially at 5 degree Celsius in inlet. The design was completed on the extreme ambient condition.

Since, the heating temperature at the

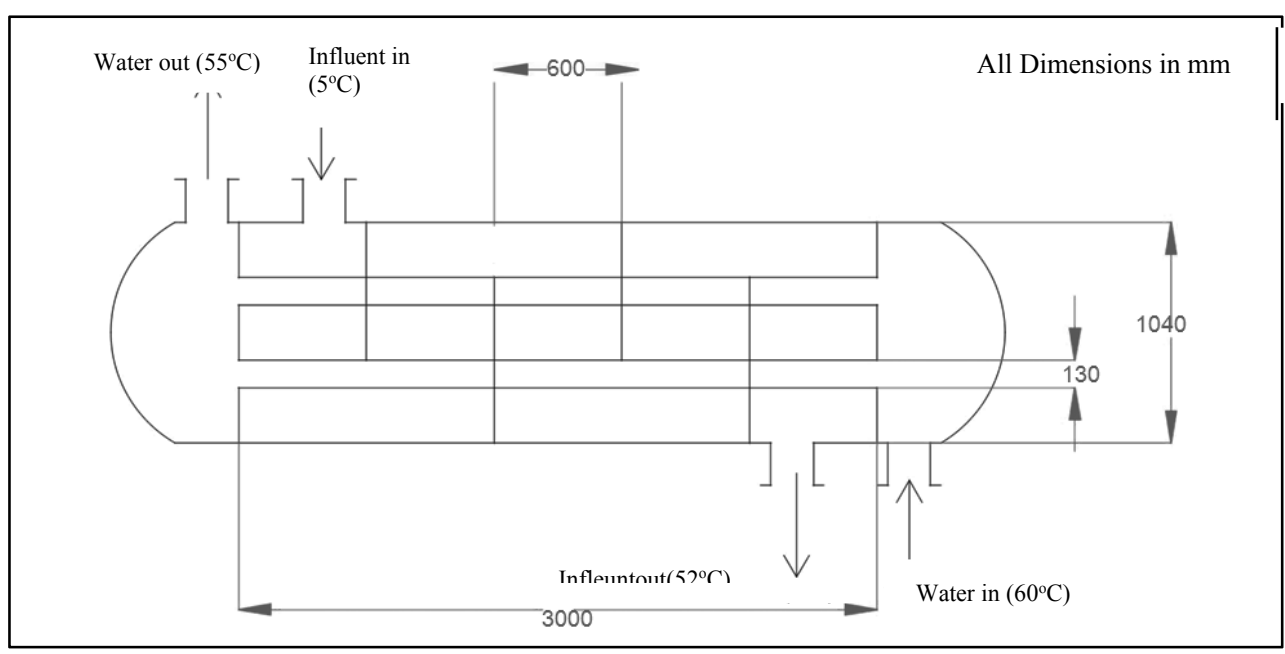

Figure 2: Heat Exchanger for Pre-Heating Influent.

outlet of influent is about 52 degree Celsius and the temperature of the heating water is at about 60 degree Celsius, the shell and tube can be the best alternative. For heating the digester, some researchers have also used counter flow type of heat exchangers. The design procedure and calculation for the heat exchanger has been completed under the standard procedure of heat transfer during forced convection. 
The ambient temperature of sludge is never certain. The design condition has been considered for the extreme case of ambient temperature i.e. 5 degree Celsius. In the case of fluctuations of temperature of influent manure, the time for heating fluctuates along with mass flow rate requirement. The flow requirement for hot water is about 0.7 kilograms for second and for influent manure to be 0.08 kilograms per second.

Temperature vs Time

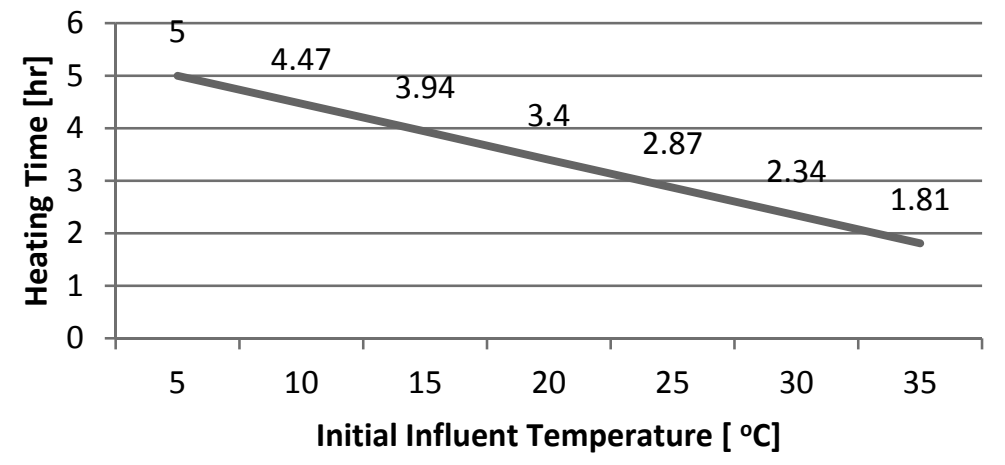

Figure: 5 Initial Influent Temperature over Heating Time.

When the ambient temperature of manure is about 5 degree Celsius, the total time required for heating the mass of 1555 kilograms of influent manure and its mass flow rate is about 5 hours and 0.09 kilograms per second. Similarly, when the ambient temperature of increases, the time for heating decreases consequently accommodation is required for the mass flow rate i.e. mass flow rate must be increased accordingly.

\section{Insulation}

\section{Heat Loss before Insulation}

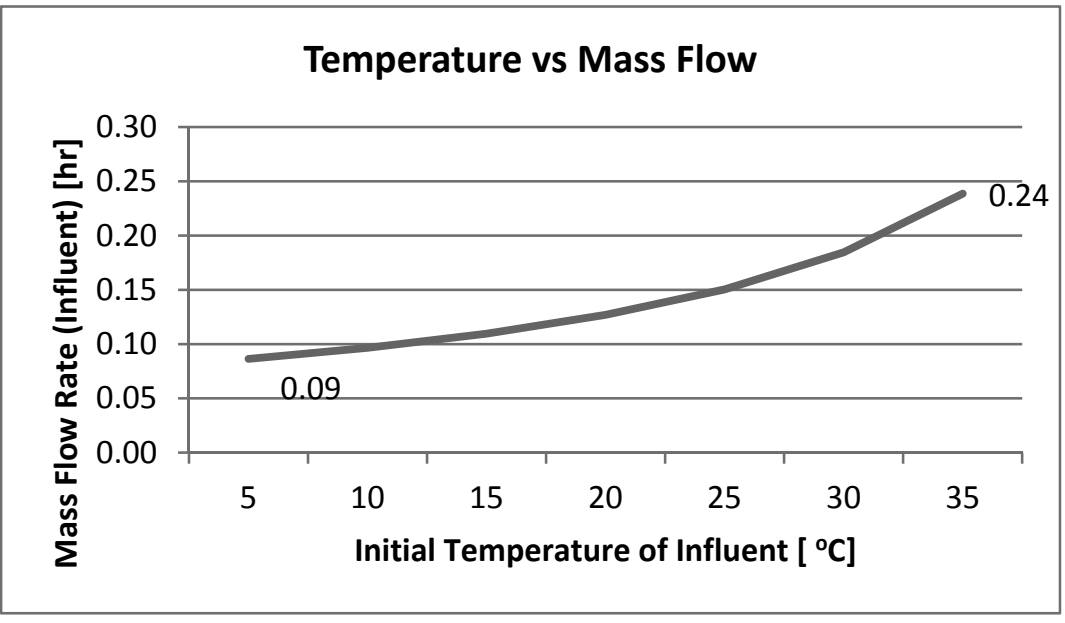

Figure 3: Initial Temperature of Influent vs Mass Flow Rate

In the digester the heat loss occurs due to the conduction of heat from higher temperature to lower temperature. To design the effective heating system, it is very necessary to take account on these heat losses.

There are three surfaces from which heat is transferred to the surroundings i.e. wall, roof and floor. The heat loss from these surfaces must be considered before designing the heat exchanger for digester.

\begin{tabular}{|c|c|c|c|c|}
\hline Structure & $\begin{array}{c}\text { Area } \\
\mathbf{( m}^{\mathbf{2}} \mathbf{)} \mathbf{A}\end{array}$ & Thickness (m), $\mathbf{L}$ & $\begin{array}{c}\text { Thermal } \\
\text { Conductivity } \\
\mathbf{( W / m - K )}, \mathbf{K}\end{array}$ & Material \\
\cline { 1 - 3 } Wall & 14 & 0.15 & & Concrete \\
\hline Roof & 18.70 & 0.15 & \multirow{2}{*}{1.70} & Concrete \\
\hline Floor & 15.55 & 0.35 & & $0.15 \mathrm{~m}$ Concrete \\
\cline { 5 - 5 } & & & & $0.20 \mathrm{~m}$ Stone \\
\hline
\end{tabular}




\begin{tabular}{|l|l|l|r|}
\hline Heat Loss & Formula & Value & Remarks \\
\hline \multirow{2}{*}{ Wall } & \multirow{3}{*}{$\frac{K A\left(T_{d}-T_{a}\right)}{2}$} & $7140 \mathrm{~W}$ & \\
Roof & & $9537 \mathrm{~W}$ & \multirow{2}{*}{$T_{d}=55^{\circ} \mathrm{C}$} \\
Floor & $3398 \mathrm{~W}$ & $T_{a}=10^{\circ} \mathrm{C}$ \\
\cline { 3 - 3 } Total Heat loss $\left(\mathrm{Q}_{\mathrm{L}}\right)$ & & $\begin{array}{l}20075 \mathrm{~W} \\
=20.075 \mathrm{KW}\end{array}$ & \\
& & & \\
\hline
\end{tabular}

The heat loss from surface of the bio gas digester is calculated to be $20.075 \mathrm{KW}$. It is necessary to design the insulating system to prevent this heat loss.

\section{Heat Loss after Insulation}

Heat loss due to conduction is very high. Thus, insulating material is used to prevent the heat loss. Considering the insulating material is glass wool of thermal conductivity $0.04 \mathrm{~W} / \mathrm{m}^{2} \mathrm{~K}$ of $6 \mathrm{~cm}$ thickness.

\begin{tabular}{|l|l|l|l|l|}
\hline Structure & $\begin{array}{l}\text { Thermal Resistance } \\
\boldsymbol{R}_{\mathbf{1}}=\frac{\boldsymbol{L}}{\boldsymbol{K} \boldsymbol{A}}\end{array}$ & $\begin{array}{l}\text { Insulation } \\
\text { Resistance } \\
\boldsymbol{R}_{\mathbf{2}}=\frac{\boldsymbol{L}}{\boldsymbol{K A}}\end{array}$ & $\begin{array}{l}\text { Total } \\
\boldsymbol{R}=\boldsymbol{R}_{\mathbf{1}}+\boldsymbol{R}_{\mathbf{2}}\end{array}$ & $\begin{array}{l}\text { Heat Loss } \\
\boldsymbol{Q}=\frac{\left(\boldsymbol{T}_{\boldsymbol{d}}-\boldsymbol{T}_{\boldsymbol{a}}\right)}{\boldsymbol{R}}\end{array}$ \\
\hline Wall & 0.006303 & 0.107143 & 0.113445 & $396.67 \mathrm{~W}$ \\
\hline Roof & 0.004718 & 0.0080214 & 0.084932 & $529.83 \mathrm{~W}$ \\
\hline Floor & 0.01324 & 0.096463 & 0.109703 & $410.20 \mathrm{~W}$ \\
\hline \multicolumn{2}{l}{ Total Heat loss $\left(\mathrm{Q}_{\mathrm{L}}\right)$} & & $1336.698 \mathrm{~W}$ \\
\hline
\end{tabular}

Hence, there is significant improvement on the total heat loss from the conducting surfaces after using the glass wool as an insulating material which has thickness $6 \mathrm{~cm}$.

\section{Heat Requirement for Digester}

The heating of digester for maintaining the operating temperature of the digester is a very difficult process. Even drop in temperature for very short time can halt the overall process. The heating range is about 53-58 degree Celsius.

One of the biggest challenges is to maintain

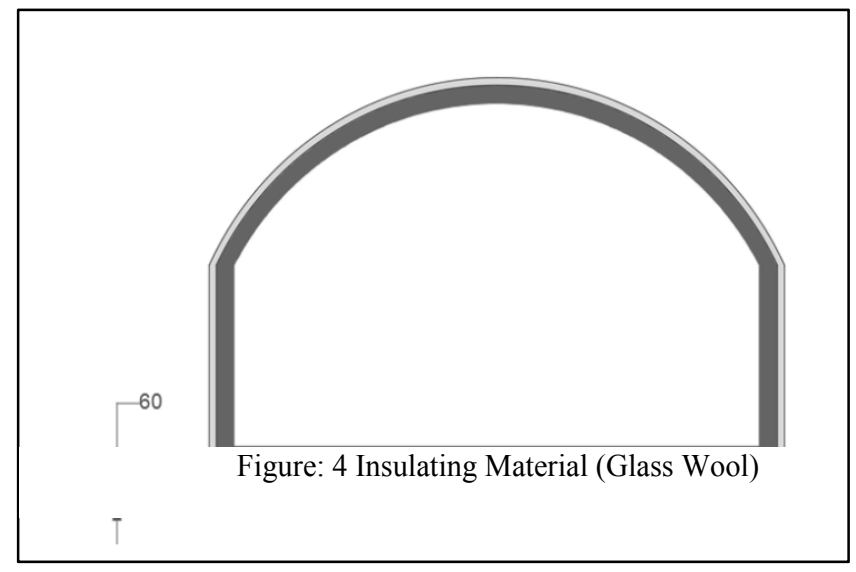
the operating temperature for heating with small temperature difference at the hot fluid side at heat exchanger. This is because, the thermophile bacteria is very sensitive towards temperature. It will be inactive, if the temperature of sludge goes beyond 60 degree Celsius.

Since, there is no opportunity to work on high temperature the effective solution for the problem could be using more than one heat exchanger continuously adding the heat to the influent manure, so that its temperature remains within operating range. 


\begin{tabular}{|l|l|l|l|}
\hline \multicolumn{2}{|l|}{ Parameters } & Value & Unit \\
\hline \multirow{2}{*}{ Hydraulic Retention Time (HRT) } & Water & 15 & days \\
\cline { 2 - 5 } & Manure & 855 & $\mathrm{~kg} / \mathrm{day}$ \\
\cline { 2 - 5 } & Total & 700 & $\mathrm{~kg} / \mathrm{day}$ \\
\hline \multirow{2}{*}{$\begin{array}{l}\text { Final temperature } \\
\text { Heat loss due to conduction }\end{array}$} & 23325 & $\mathrm{~kg}$ \\
\hline \multirow{3}{*}{$\begin{array}{l}\text { Total Requirement } \\
\text { Accounting Conduction Loss for } \\
\text { Different Temperature }\end{array}$} & $40^{\circ} \mathrm{C}$ & 56 & $\mathrm{o} \mathrm{C}$ \\
\cline { 2 - 5 } & $35^{\circ} \mathrm{C}$ & 116 & $\mathrm{MJ}$ \\
\cline { 2 - 5 } & $45^{\circ} \mathrm{C}$ & 2276 & $\mathrm{MJ}$ \\
\cline { 2 - 5 } & $50^{\circ} \mathrm{C}$ & 1860 & MJ \\
\cline { 2 - 5 } & $53^{\circ} \mathrm{C}$ & 614 & MJ \\
\hline
\end{tabular}

The above table shows the total heat requirement for maintaining the heat of the digester at different starting temperatures. To heat the digester initially at 30 degree Celsius to 56 degree Celsius, a total of 2276 mega joule of heat is required. Similarly, to heat digester from 50 degree Celsius to 56 degree Celsius, a total heat of $614 \mathrm{MJ}$ is required to maintain the operating temperature.

\section{Heat Exchanger for digester}

The heat loss from the digester is due to the conduction between the walls of digester with the outer surroundings. The digester will be at operating temperature most of the time. If we consider designing the heat exchanger for heating the influent initially at 30 degrees, overall cost of heating equipment increases while there won't be much more contribution of the heating equipment that would be useful in maintaining the operating temperature.

At the normal operating condition the temperature of digester is never 30 degree Celsius. But it can

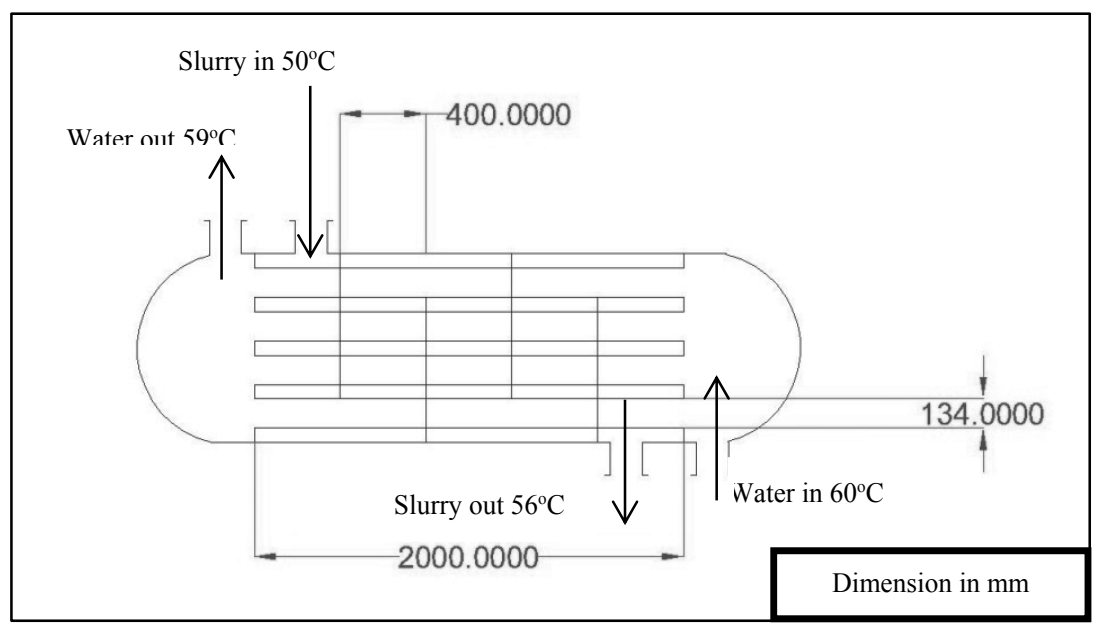

Figure 5: A Heat Exchanger for Digester. 
drop its temperature if the heating operation discontinues for long time or it's the case of initial starting. So, the selection has been done on the basis of optimum utilization of resources along with the consideration of time in the time of necessity to maintain the overall heat.

If it's designed to heat the digester at 50 degree Celsius to 56 degrees Celsius with in five hours, then same system can maintain the digester temperature initially at 30 degree to 56 degrees within 16 hours of heating operation.

A heat exchanger for the following dimensions has been designed to maintain the overall heat of the digester to 56 degree Celsius. When the inlet temperature of the hot water at tube is at 60 degrees and outlet temperature of the water to be 59 degree Celsius, the heat exchanger is capable to maintain the temperature of the slurry entering the heat exchanger's shell at the temperature of 50 degree Celsius to 56 degree. The total mass of heat exchanger could be circulated within 5 hours. The total number of five heat exchanger has been used for maintain the overall digester temperature.

Some other specifications of the heat exchanger have been listed on the table.

\begin{tabular}{|l|l|r|l|}
\hline S.N & Parameters & Value & Unit \\
\hline 1 & Total Heat Required & 614 & $\mathrm{MJ}$ \\
\hline 2 & Temperature of Influent manure in (Cold) & 56 & ${ }^{\circ} \mathrm{C}$ \\
\hline 3 & Temperature of Influent manure out (hot) & 60 & ${ }^{\circ} \mathrm{C}$ \\
\hline 4 & Temperature of water in (hot) & 0.32 & $\mathrm{Kg} / \mathrm{s}$ \\
\hline 5 & Mass flow rate of Influent & 1.62 & $\mathrm{Kg} / \mathrm{s}$ \\
\hline 6 & Mass flow rate of water & 5 & $\mathrm{hr}$ \\
\hline 7 & Time Required & 5 & \\
\hline 8 & No of Heat Exchangers & 0.130 & $\mathrm{~m}$ \\
\hline 9 & Diameter of tube & 6 & $\mathrm{~m}$ \\
\hline 10 & Total Length & 558 & $\mathrm{~W} / \mathrm{m}^{2} \mathrm{~K}$ \\
\hline 11 & Overall Heat Transfer Coefficient & 5.1 & ${ }^{\circ} \mathrm{C}$ \\
\hline 12 & Log Mean Temperature Difference & & \\
\hline
\end{tabular}

\section{Conclusions}

Theoretically, heat exchangers have been designed for thermophilic temperature following the standard procedure and heat transfer equations. There are altogether six shell and tube heat exchangers to heat the influent manure. Among them, one is for pre heating of influent manure, to prevent sudden drop in the temperature of the digester when manure is poured at digester. The five other heat exchanger heat the influent from the digester, for maintaining the temperature to 60 degree 
Celsius. The heating capacity for five heat exchangers is about 614 mega Joules within 5 hours of operation. Similarly, the heating capacity for heating influent manure is about 260 mega joules within in 5 hours.

Five heat exchangers can work independently, at a mass flow rate of $0.32 \mathrm{~kg} / \mathrm{s}$ each at shell side, to heat the influent initially at 50 degree Celsius to 56 degree Celsius. The hot water at the tube side of the heat exchanger has the mass flow rate of $1.62 \mathrm{~kg} / \mathrm{s}$, with inlet temperature of 60 degree Celsius. Similarly, for the preheating of influent manure, a mass flow rate of $0.09 \mathrm{~kg} / \mathrm{s}$ at the shell side, to heat the influent initially at 5 degrees to 52 degree Celsius. The hot water at the tube side of this exchanger has the flow rate of $0.7 \mathrm{~kg} / \mathrm{s}$ with inlet temperature of 60 degrees.

The hot water ( 60 degree) flowing at the tube side of the heat exchanger has the high temperature \& high flow rate while the manure (50 degree) entering at the shell side has the low temperature \& low flow rate. The heat lost from the hot water is gained by manure at the heat exchanger to maintain the temperature to 56 degree Celsius

Insulating material, glass wool which has low thermal conductivity of $0.04 \mathrm{~W} / \mathrm{m}^{2} \mathrm{~K}$ with thickness $6 \mathrm{~cm}$ has been used for digester. After insulation, there is significant reduction in loss of heat from digester i.e. from 20 kilowatts to 1.34 kilowatts. The bio gas production from the plant is about 28 cubic meters per day and the mass of manure required for the production is about 700 kilograms.

\section{Recommendations}

Based on the research, following recommendations has been drawn.

- To further continue this research work, it is recommended to work on control and automated system.

- The results are on the basis of theoretical references and it is better recommended to develop the prototype or perform flow simulation to further validate the result.

- For thermophilic range, the digestion process is highly dependent on temperature. So, it is better not to use solar heating.

\section{References}

1. Abbasi, T., S.M, T. \& S.A, A., 2012. Biogas Energy. "SpringerBriefs in Enviromental Science 2".

2. Alternate Energy Promotion Center, 2017. "History of Biogas in Nepal”. [Online] Available

at: http://www.aepc.gov.np/?option=nrrep\&page=subtechsupport\&mid=5\&sub $\mathrm{id}=37 \& \mathrm{i}$ $\underline{\mathrm{d}=4}$ [Accessed 3006 2017].

3. Alternate Energy Promotion Center, 2017. "Biogas/ Waste to Energy (W2E)". [Online] Available at: http://www.aepc.gov.np/?option=renewable\&page=subrenewable\&mid=2\&sub $\mathrm{id}=1$

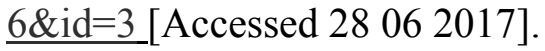

4. Alternative Energy Promotion Center - NRREP, 2014. "BIOGAS CALCULATION TOOL USER'S GUIDE”, s.1.: s.n.

5. B., D., V., S. \& S., J., 2014. "Biogas Generation through Anaerobic Digestion Proces-An Overview”. Research Journal of Chemistry and Environment, Volume 18, pp. 80-93. 
6. Basnet, K., 1989-92. “Temperature Variation in Nepal”. The Himalayan Review, Volume xx-xxiii, pp. 25-34.

7. Chynoweth, D. P., Owens, J. M. \& Legrand, R., 2001. "Renewable methane from anaerobic digestion of biomass". Renewable Energy, pp. 1-8.

8. El-Mashad, H. \&. L. W. \&. Z. G. \&. B. G. \&. L. G., 2005. “A dispersion based model for anaerobic digestion of solid cattle wastes in a stratified thermophilic accumulation system". a journal of the International Association on Water Pollution Research, pp. 195-202

9. Girard, M. et al., 2013. "Biodegradation in Animal Manure Management". s.1.:s.n

10. Hill, D. T., 1982. "Energy Consumption Relationships for Mesophilic”. Structures and Environment Div. of ASAE.

11. Luleva, M., n.d. The Green Optimistic. [Online] Available at: https://www.greenoptimistic.com/biogas-plant-backyard/\#.WWxS04SGPIV[Accessed 0907 2017].

12. M. DURAN, R. S., 1997. “Temperature-Staged Anaerobic Process”. Environmental Technology, Volume 18, pp. 747-754

13. Mc Carty, P., 1982. "One hundred years of anaerobic treatment". Elsevier Biomedical, Amsterdam, pp. 3-22.

14. Meteorological Forecasting Division, 2010. "Government of Nepal, Department of Hydrology and Meterology". [Online] Available at: http://www.mfd.gov.np/city?id=31[Accessed 0106 2017].

15. T. M. ALKHAMIS, R. E.-K. M. M. K. a. M. A. A., 2000. "HEATING OF A BIOGAS REACTOR USING A SOLAR ENERGY SYSTEM”. Solar Energy, Volume 69, pp. 239-247.

16. Zeeman, G., 1991. "Mesophylic and psychrophilic digestion of liquid manure". Research Gate, p. 116. 